\title{
Ecological macroeconomics: reflections on labour markets*
}

\author{
Sigrid Stagl \\ Department of Socioeconomics, WU (Vienna University of Economics and Business), and WIFO (Austrian \\ Economic Research Institute), Vienna, Austria
}

The paper outlines elements of ecological macroeconomics and implications for labour markets. It discusses reasons for growth restrictions and options for measuring the biophysical basis of economic production. The paper then goes on to explore implications for labour markets and implications for environmental and social policies.

Keywords: ecological macroeconomics, sustainable work, measurement of well-being

JEL codes: E02, E24, I31, J08, Q50

\section{INTRODUCTION}

Modern economies are structurally dependent upon continued economic growth and orthodox macroeconomics assumes that economies will grow indefinitely. Yet global environmental change changes everything. It is the 'elephant in the room' that can no longer be ignored. Global environmental change alters our life support systems, the very basis of life humans depend on. In many ways, it affects our chances of survival, our livelihoods, development options, economic structure and lifestyles - in short the whole political economy. It changes everything for those of us making decisions that affect the human-made and natural environment, and for those of us trying to understand the profound changes unfolding around us.

Total anthropogenic greenhouse gas emissions continued to increase between 1970 and 2010 with larger absolute decadal increases toward the end of this period (IPCC 2014). Biodiversity has continued to decline globally (Butchart et al. 2010). Global extraction of natural resources from ecosystems and mines has grown more or less steadily over the past 25 years (Dittrich et al. 2012). Recent estimates from IPCC scientists suggest that per-capita emissions in developed nations must be reduced by $80-95$ per cent by 2050 if global warming is to be limited to the internationally agreed threshold of $2^{\circ} \mathrm{C}$ above the pre-industrial value. The challenge of staying within such biophysical limits conflicts with existing patterns of economic growth, which are dependent on the increased use of energy and other resources. While relative decoupling of GDP and environmental pressure has been achieved (higher eco-efficiency), we have not achieved the more important absolute decoupling, which would signify a reduction of the total amount of natural resource use.

To date, the biophysical environment is poorly represented in most macroeconomic models. Accounting for nature is usually an afterthought to the real business of 'doing economics' - that is, suggesting policies for increasing GDP. The implicit assumption

* Paper presented at the FMM Conference, Berlin, 24-26 October 2013. 
is that nature is a fixed, indestructible factor of production. The problem with viewing nature in this way is that it is wrong: ecosystems generally are self-regenerative, but suffer from depletion or deterioration when overused. 'To assume away the physical depreciation of capital assets is to draw a wrong picture of future production and consumption possibilities that are open to a society' (Dasgupta 2010).

Ecological economic analysis normally starts from the premises of: (1) limited substitutability of production factors; (2) valuing the natural environment more fully for contributing to the production of marketed goods and services as well as human welfare without ever passing through markets; and (3) accounting for biophysical feedbacks, while acknowledging their often non-linear nature, the role of accumulating effects and fundamental uncertainty.

It has been said before that ecological economics and post-Keynesian economics have some common ground (Holt et al. 2010). Both go beyond a concern for economic efficiency and growth by moving inequity to the centre of the analysis and usually account for uncertainty. Additionally, ecological macroeconomics aims to augment the analysis by accounting for: (1) impacts over the very long term; and (2) the overall (not just per-unit) biophysical impact of the economy.

Fontana/Sawyer (2013) recently outlined in this journal an approach to ecological macroeconomics based on post-Keynesian and Kaleckian ideas. They started from the empirically well-founded assumption that growth of aggregate demand tends to be greater than sustainable or 'nature constrained' growth. Building on their ideas, I aim to contribute to the emerging field of ecological macroeconomics by giving an overview of measurement options of biophysical impacts and reflecting on the implications of environmental change on labour markets. The lack of ecological economic analysis of labour markets and related problems has become a major stumbling block for climate policy and other environmental policies.

Several other themes are of critical importance yet outside the scope of this paper: policies aiming more explicitly for well-being and insights from happiness economics (Ferrer-iCarbonell 2013), the need to address financialisation and its implications for the real economy and the environment (Arestis/Sawyer 2010; Stockhammer 2004), reorganising economic institutions towards a care economy (Nelson 2008; Netzwerk Vorsorgendes Wirtschaften 2012).

\section{ECONOMIC GROWTH AND BIOPHYSICAL BOUNDARIES}

\subsection{Limits to Growth}

The Limits to Growth world model by Meadows et al. (1972) was built specifically to investigate five major trends of industrialisation, population growth, malnutrition, depletion of non-renewable resources, and a deteriorating environment. The model sought to understand the causes of these trends, their interrelationships, and their implications as much as 100 years in the future.

The Limits to Growth team was concerned that, despite earlier similar research finding, the vast majority of policymakers seems to be actively pursuing goals that are inconsistent with these results.

The World3 model, on which the analysis of Limits to Growth was built, consisted of a food system, industrial system, population system, non-renewable resources system, and a pollution system. Limits to Growth model runs (standard, increased resource use, sustainable) were not intended as predictions, but as scenario analyses. 
Meadows et al. (1972: 24) concluded:

(1) If the present growth trends in world population, industrialization, pollution, food production, and resource depletion continue unchanged, the limits to growth on this planet will be reached sometime within the next one hundred years. The most probable result will be a rather sudden and uncontrollable decline in both population and industrial capacity. (2) It is possible to alter these growth trends and to establish a condition of ecological and economic stability that is sustainable far into the future. The state of global equilibrium could be designed so that the basic material needs of each person on earth are satisfied and each person has an equal opportunity to realize his individual human potential. (3) If the world's people decide to strive for this second outcome rather than the first, the sooner they begin working to attain it, the greater will be their chances of success.

Unfortunately the report was largely dismissed by critics as a doomsday prophecy instead of an analysis aiming to aid policymaking. The main points of criticism were the pessimism about innovation built into the model and resource prices not being included in all runs.

Recent evaluations yield interesting insights. 'The analysis shows that 30 years of historical data compare favorably with key features of a business-as-usual scenario called the "standard run" scenario, which results in collapse of the global system midway through the $21^{\text {st }}$ century. The data do not compare well with other scenarios involving comprehensive use of technology or stabilizing behaviour and policies' (Turner 2008: 397). Hall/Day (2009: 233) noted that ' $[t]$ he values predicted by the limits-to-growth model and actual data for 2008 are very close'. And even clearer: 'The warnings that we received in $1972 \ldots$ are becoming increasingly more worrisome as reality seems to be following closely the curves that the ... scenario had generated' (Bardi 2011: 3).

Not least due to the current situation of multiple crises, there has been a resurgence of interest in the economics of low growth, no growth and degrowth in high consumption economies in recent years. Starting from the premise that resource and $\mathrm{CO}_{2}$ limits render further growth unsustainable, they work on developing an alternative economic narrative and alter the dominant economic discourse (Kallis 2011; O'Neill 2012; Schneider et al. 2010; Sekulova et al. 2013; Sorman/Giampietro 2013; van den Bergh 2011; van den Bergh/Kallis 2012; Victor 2012; Videira et al. 2014). They argue for developing alternative development pathways, rather than relying on technology to get them out of the growth dilemma - especially since evidence shows that improvements in technological efficiency are often offset by increases in the overall scale of the economy.

\subsection{Biophysical boundaries and risks}

A growing body of scientific evidence points at critical thresholds, or 'tipping points' in the functioning of the Earth system. Crossing these thresholds leads to fundamentally different configurations of the Earth's physical and ecological dynamics. This disrupts the structures and processes of the Earth's ecosystems, which provide beneficial but often unrecognised services on which humanity fundamentally depends. These ecosystem services include processes like climate regulation, the maintenance of genetic diversity of life, the decomposition and detoxification of waste, and the vital functions of the water and nutrient cycles. Ecosystems also play an obviously crucial role in the provision of essential resources such as food, fibre and fuels. Abrupt shifts to new environmental states therefore challenge society's capacity to respond and adapt.

Economic activity entails processes which interact with the biophysical sphere in various forms. Although the Earth has undergone many periods of significant environmental change 
(Diamond 2005; Ponting 1991; Weisz et al. 2001), the planet's environment has been unusually stable for the past 10000 years. This period of stability - known to geologists as the Holocene ('the entire new') - has seen human civilisations arise, develop and thrive.

Exploring the level of interference of humans with natural systems, Rockström et al. (2009) suggest that we may be close to leaving the safe operating space as measured by nine key earth system boundaries including the level of ocean acidification, rate of global freshwater use and chemical pollution. Three thresholds (greenhouse gas concentrations, rate of biodiversity loss, nitrogen removal from the atmosphere for human uses) may actually have been overstepped, which is shown in Figure 1 .

Given the broad range and extent of direct and indirect interference with world ecosystems caused by human activity, Rockström et al. (2009) consequently underscore the proposal of Crutzen/Stoermer (2000) of relabeling our current geological age from Holocene to Anthropocene ('the human new') (Kellie-Smith/Cox 2011; Steffen et al. 2011; Tickell 2011; Vidas 2011; Zalasiewicz et al. 2011).

Planetary boundaries propose the outer limits of pressure that humanity should place on critical Earth systems in order to protect human well-being. Empirical analyses on the Environmental Kuznets Curve hypothesis have illustrated that there is mixed evidence on the relationship between economic growth and the various dimensions of environmental quality; certainly there is no systematic empirical support for the hypothesis that higher per capita income correlates with lower environmental pressure (Stern et al. 1996; Stagl 1999; Stern 2004). Others questioned the long-term feasibility of economic growth

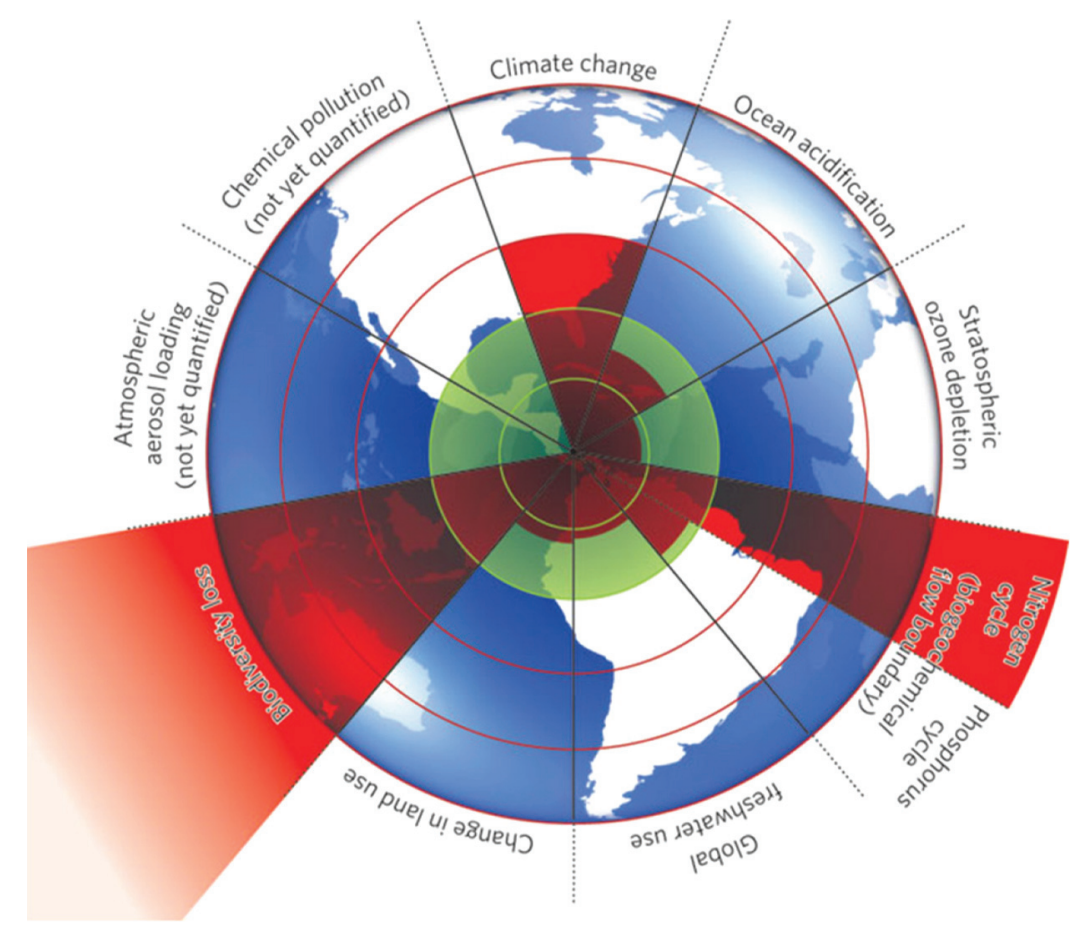

Source: Rockström et al. (2009).

Figure 1 Earth system boundaries and human interference 
(Arndt 1978; Ayres/Warr 2009; Hamilton 2003; Jackson 2009; Porritt 2007; Victor 2008). They point out that economic growth is positively correlated with the use of natural resources and that high-income economies are already operating on a scale and with an intensity that cannot be sustained by the carrying capacity of ecosystems in the long run. They emphasise that economic activity based on the cheap availability of resources is not expected to last far into the twenty-first century, undermining a fundamental condition on which past economic growth has been based. Meadows et al. (1972; 2004), for example, argued that more capital will be necessary in the future to provide people and the economy with natural resources, which will ultimately lead to a slowdown in economic growth itself.

Hirsch (1976) had highlighted another development, namely the weakening link between economic growth and quality of life, access to education and social mobility.

While difficult to pinpoint precisely, natural scientists have recently made progress in understanding critical global thresholds or 'tipping points'. The best summary of the current science is in the IPCC's 2013 Fifth Assessment Report, Working Group I, The Physical Science Basis, section 12.5 (Collins et al. 2013).

\subsection{Ecological footprint}

Footprint accounting attempts to answer the following question: how much do people demand from ecosystems compared to what those ecosystems (or the biosphere as a whole) can regenerate? Its purpose is to measure how big an economy's metabolism is compared to nature's ability to provide for this metabolism. It is an accounting tool and aggregate indicator measuring human appropriation of ecosystem products and services in terms of the amount of bioproductive land and sea area needed to supply these products and services. Based on two accounts (biocapacity and footprint) representing the supply and demand of renewable biological resources across six mutually exclusive land-use types: cropland, grazing land, forest, fishing ground, built-up land and the area of forest required to offset human carbon emissions. Biocapacity and footprint of consumption are both converted into 'global hectares'. Footprint accounting is used by scientists, environmental organisations and popular media to visualise the biophysical impact and changes thereof.

Wackernagel/Rees (1996) developed the framework, which translates all biophysical impacts in area units. The Global Footprint Network has extended the conceptual base by comparing the footprint to the availability of biocapacity and has substantially increased the scope of the empirical work. While the evidence differs by regions and countries, the footprint work concludes that current biocapacity is smaller than the demand.

Indices such as the ecological footprint, but also quality of life indices (OECD), index of sustainable economic welfare (Cobb et al. 1994; Stockhammer et al. 1997) or the human development index (UNDP 2013) have the advantage of being able to communicate complex conditions in crisp numbers and clear trends. However, they have also been criticised for covering rather than unpacking crucial changes, interactions and conflicts, which is why they should always be accompanied by an analysis of the richer picture underlying changing indices. The ecological footprint was recently criticised by Giampietro/Saltelli (2014) and van den Bergh/Grazi (2014). ${ }^{1}$

Hence, while it is tempting to use a single metrics to account for the complexity of biophysical impacts, for macroeconomic modelling it seems more advisable to include

1. See also Wackernagel's (2014) reply. 
the key environmental variables (in their respective physical unit) that are relevant for the question the model aims to address.

\section{BIOPHYSICAL LIMITS, EMPLOYMENT AND LABOUR MARKETS}

\subsection{Going beyond 'green jobs'}

With economic growth slowing down for several reasons, the concern of increasing unemployment is high. Green growth has been dubbed as an avenue to combine higher incomes with lower environmental impacts (OECD 2011). The crucial point here is that green growth initiatives usually refer to environmental impacts per unit and not the overall environmental impact (impact per unit times quantity produced).

'Green innovations', as well as energy and resource efficiency, are expected to deliver growth, jobs and lower environmental impacts. For several reasons, these measures tend to be too weak to make significant progress in environmental terms:

First, rebound effects can be: (i) direct behavioural responses to greener technology (for example, driving further in a fuel-efficient car); (ii) indirect behavioural responses (for example, spending the money saved on heating on an overseas holiday); and (iii) increased productivity leading to economic growth. To avoid energy and resource efficiency gains from undermining the benefits to climate and resource policy, building 'headroom' into policy targets to allow for rebound effects, raising energy/resource prices in line with efficiency improvements or imposing absolute caps on emissions or material use have been suggested (Chitnis et al. 2013; Druckman et al. 2011; Sorrell/Dimitropoulos 2008; Sorrell et al. 2009).

Second, the reorientation of productive corporations towards financial market performance, especially in the United States and UK, has adversely affected their innovative capacity, helping to explain these countries' relatively laggard environmental performance (Fieldman 2014).

While it is reasonable, even necessary, to approach environmental challenges from a socio-economic angle and starting with jobs is plausible, the proposed measures nevertheless often focus on categorising the greenness and counting them, rather than transforming resource or labour markets.

ILO (2013) defines green jobs as 'decent jobs that contribute to preserve or restore a sustainable environment, be they in traditional sectors such as manufacturing and construction, or in new, emerging green sectors such as renewable energy and energy efficiency'. The associated efficiency and protection measures remain vague. Much of the conceptual and empirical work has focused on distinguishing green jobs as employment in production of green products and services as opposed to employment in environmentally friendly processes or decent work. Until green job policies become part of socio-ecological transformation and we start rethinking economic structures and consider including care work and other valuable work, green jobs will remain an accounting framework resulting from environmental technologies and environmental policies with little of their own merit.

\subsection{The role of working time for a sustainable economy}

Keynes famously predicted that rates of productivity, driven by technological change, would rise so rapidly that by the twenty-first century no one would need to work more than 15 hours a week. 'Three-hour shifts or a fifteen-hour week may put off the problem for a great while' (Keynes 1930 [1963]: 369). While Keynes was roughly right in his estimates of productivity increase, his expectation of the workers' response was wrong. Instead 
of reducing working hours, people find new things to desire. Consumer culture stimulates ever-increasing demand with reference points continuously shifting upwards. Increasing variety of consumption items offered in the markets and increasing specialisation of the consumers in their demand activities play a key role (Witt 2001). Yet Keynes (1930 [1963]: 368) did see that appreciating more leisure would require a different way of thinking: 'Yet there is no country and no people, I think, who can look forward to the age of leisure and of abundance without a dread. For we have been trained too long to strive and not to enjoy. It is a fearful problem for the ordinary person, with no special talents, to occupy himself ...'.

Historically, working hours have declined. From 16 hours daily in 1820 to 8 hours today, from 80 hours weekly to 40 or 38 hours; while paid leave has risen from 2 weeks per year to 5 or 6 weeks in many countries. Yet with increased female participation in the labour force, household labour supply increased from 60 hours in 1885 to $70-75$ hours today (Eurostat 2012). Some wage-earners had unambiguously rising weekly working hours since the 1980s to counteract lower hourly wages and rising social pressure for consumer goods (Schor 1991).

Instead of reducing working hours as an individual choice, the New Economics Foundation (NEF) suggests reducing the norm working hour. Their reasoning goes beyond redistributing the labour volume to more people; a much shorter working week would, the NEF argues, change the tempo of our lives, reshape habits and conventions, and profoundly alter the dominant cultures of western society. "A "normal" working week of 21 hours could help to address a range of urgent, interlinked problems: overwork, unemployment, over-consumption, high carbon emissions, low well-being, entrenched inequalities, and the lack of time to live sustainably, to care for each other, and simply to enjoy life' (Coote et al. 2010: 2).

At the same time, 40-hour paid working weeks are no longer the norm in most countries. Depending on the industry, we observe much shorter contracts and varying weekly hours. However, like the NEF, Coote/Franklin (2013: x) argue for shorter working weeks, expecting this would be 'better for people, for the planet and for the beleaguered postindustrial economy'.

It is a recent phenomenon that unions and workers' representatives have shown increased interest in the (voluntary) option of reducing working time. The Netherlands and Denmark are real case studies that well-being can be increased and environmental performance improved by reducing working hours. However, as long as energy and resource prices are low, the question of the environmental implications of increased leisure time is an empirical one; it depends on what workers do in their leisure time (for example, compare spending time at the library and reading with going on an extra holiday and taking a long-haul flight).

\subsection{Labour productivity and its interdependence with resource productivity}

The relationship between economic growth and the change in employment is influenced by labour supply, labour productivity, demand for types of products, working time, etc.; changes in employment and unemployment rates are due to hidden domestic labour reserves, additional foreign workers, demographic factors, participation rates, labour market institutions, labour market history, norms, reaction to employment opportunities, etc., and accounting for impacts on income distribution influenced by financialisation, globalisation, labour market institutions, technology is increasingly considered. It is well documented that the long-term impact of output fluctuations on unemployment rate dynamics is mixed, depending on the technologies in use and labour market 
institutions (IMF 2010). Yet what is the role of resource availability and resource productivity for the labour market?

If prices of energy were to rise further, other commodity prices would follow suit. High resource prices could lead to a shift in the dominant mode of cost reduction from labour to resources. In this case, it would not be the increase of labour productivity that would be the key measure, but the saving of resources, possibly at the expense of more labour. For the economy as a whole, this would mean a shift in relative prices between material goods and labour, and consequently a decline in demand for material goods and increasing demand for labour. As far as economic growth depends on rising labour productivity, it would be dampened. Increasing care work and other service activities would have an impact in the same direction, as service labour productivity cannot increase much. In effect, the purchasing power of workers would be reduced, and distributional conflicts about wages would become more frequent. Hence, pre-distribution and re-distribution policies, and income policies in general, need to play a greater role in combining ecological and social concerns.

What could lead to such a steep increase in prices? I mentioned above the internationally agreed $2 \mathrm{C}$ goal. Limiting fossil fuel use to the respective carbon budget, 'unburnable carbon' has significant implications on fossil fuel availability (Carbon Tracker 2013): already in 2011, the world has used over a third of its 50-year carbon budget of 886 $\mathrm{GtCO}_{2}$, leaving $565 \mathrm{GtCO}_{2}$. All of the proven reserves owned by private and public companies and governments are equivalent to $2795 \mathrm{GtCO}_{2}$. Fossil fuel reserves owned by the top 100 listed coal and top 100 listed oil and gas companies represent total emissions of $745 \mathrm{GtCO}_{2}$. Only 20 per cent of the total reserves can be burned unabated, leaving up to 80 per cent of assets technically unburnable.

\section{CONCLUSIONS}

Stanley Jevons (1865) asked: when does the effort of working begin to exceed the value of the wage to the worker? Daly/Farley (2004: 20) posed an analogous ecological economic question: 'When does the cost to all of us displacing the Earth's ecosystems begin to exceed the value of the extra wealth produced?' Current macroeconomic models cannot address this question. In this paper I explored emerging building blocks for an ecological macroeconomics and aim to support further development of ecological macroeconomic modelling by: (1) discussing biophysical accounting options and experiences in using them; and (2) the crucial role of labour market performance and rethinking labour market institutions for achieving higher environmental sustainability.

\section{REFERENCES}

Arestis, P., Sawyer, M. (eds) (2010): 21st Century Keynesian Economics, Annual Edition of International Papers in Political Economy, Houndmills, Basingstoke: Palgrave Macmillan.

Arndt, H.W. (1978): The Rise and Fall of Economic Growth: A Study in Contemporary Thought, Sydney: Longman Cheshire.

Ayres, R.U., Warr, B. (2009): The Economic Growth Engine: How Energy and Work Drive Material Prosperity, Cheltenham, UK and Northampton, MA: Edward Elgar.

Bardi, U. (2011): Limits to Growth Revisited, Berlin and New York: Springer.

Butchart, S.H.M., Walpole, M., Collen, B., van Strien, A., Scharlemann, J.P.W., Almond, R.E.A., Baillie, J.E.M., Bomhard, B., Brown, C., Bruno, J., Carpenter, K.E., Carr, G.M., Chanson, J., Chenery, A.M., Csirke, J., Davidson, N.C., Dentener, F., Foster, M., Galli, A., Galloway, J.N., 
Genovesi, P., Gregory, R.D., Hockings, M., Kapos, V., Lamarque, J.-F., Leverington, F., Loh, J., McGeoch, M.A., McRae, L., Minasyan, A., Morcillo, M.H., Oldfield, T.E.E., Pauly, D., Quader, S., Revenga, C., Sauer, J.R., Skolnik, B., Spear, D., Stanwell-Smith, D., Stuart, S.N., Symes, A., Tierney, M., Tyrrell, T.D., Vié, J.-C., Watson, R. (2010): Global biodiversity: indicators of recent declines, in: Science, 328(5982), 1164-1168.

Carbon Tracker (2013): Unburnable carbon - are the world's financial markets carrying a carbon bubble? URL: http://www.carbontracker.org/site/wastedcapital.

Chitnis, M., Sorrell, S., Druckman, A., Firth, S.K., Jackson, T. (2013): Turning lights into flights: estimating direct and indirect rebound effects for UK households, in: Energy Policy, 55: 234-250.

Cobb, C.W., Cobb, J.B., Human Economy Center (1994): The Green National Product: A Proposed Index of Sustainable Economic Welfare, Lanham, Mankato, MN: University Press of America, Human Economy Center.

Collins, M., Knutti, R., Arblaster, J., Dufresne, J.-L., Fichefet, T., Friedlingstein, P., Gao, X., Gutowski, W.J., Johns, T., Krinner, G., Shongwe, M., Tebaldi, C., Weaver, A.J., Wehner, M. (2013): Long-term climate change: projections, commitments and irreversibility, in: Stocker, T.F., Qin, D., Plattner, G.-K., Tignor, M., Allen, S.K., Boschung, J., Nauels, A., Xia, Y., Bex, V., Midgley, P.M. (eds), Climate Change 2013: The Physical Science Basis. Contribution of Working Group I to the Fifth Assessment Report of the Intergovernmental Panel on Climate Change, Cambridge, UK and New York: Cambridge University Press, 1102-1119.

Coote, A., Franklin, J. (eds) (2013): Time is on our Side: Why we all need a Shorter Working Week, London: New Economics Foundation.

Coote, A., Franklin, J., Simms, A. (2010): 21 hours - why a shorter working week can help us all to flourish in the 21 st century, Report, London: New Economics Foundations (NEF), URL: www. neweconomics.org/publications/entry/21-hours.

Crutzen, P.J., Stoermer, E.F. (2000): The 'Anthropocene', in: Global Change Newsletter, 41, 17-18.

Daly, H.E., Farley, J. (2004): Ecological Economics - Principles and Applications, Washington: Island Press.

Dasgupta, P. (2010): Nature's role in sustaining economic development, in: Philosophical Transactions of the Royal Society B, 365(1537): 5-11.

Diamond, J. (2005): Collapse - How Societies Choose to Fail or Succeed, New York: Viking Press.

Dittrich, M., Giljum, S., Lutter, S., Polzin, C. (2012): Green economies around the world? Implications of resource use for development and the environment, Report, Vienna: SERI.

Druckman, A., Chitnis, M., Sorrell, S., Jackson, T. (2011): Missing carbon reductions? Exploring rebound and backfire effects in UK households, in: Energy Policy, 39(6), 3572-3581.

Eurostat (2012): Arbeitskräfteerhebung 2011, Luxemburg/Brüssel.

Ferrer-i-Carbonell, A. (2013): Happiness Economics, in: SERIEs, 4, 35-60.

Fieldman, G. (2014): Financialisation and ecological modernisation, in: Environmental Politics, 23(2), 224-242.

Fontana, G., Sawyer, M. (2013): Post-Keynesian and Kaleckian thoughts on ecological macroeconomics, in: European Journal of Economics and Economic Policies: Intervention, 10(2), 256-272.

Giampietro, M., Saltelli, A. (2014): Footprints to nowhere, in: Ecological Indicators, URL: https:// www.zotero.org/groups/swansevilla/items/itemKey/EEICF6FS.

Hall, C.A.S., Day, J.W. (2009): Revisiting the limits to growth after peak oil, in: American Scientist, 97(May-June), 230-237.

Hamilton, C. (2003): Growth Fetish, London: Pluto.

Hirsch, F. (1976): Social Limits to Growth, Cambridge, MA: Harvard University Press.

Holt, R.P.F., Spash, C.L., Pressman, S. (eds) (2010): Post Keynesian and Ecological Economics: Confronting Environmental Issues, Cheltenham, UK and Northampton, MA: Edward Elgar.

ILO (2013): What is a green job? URL: http://www.ilo.org/global/topics/green-jobs/news/ WCMS_220248/lang-en/index.htm (accessed 10 May 2014).

IMF (2010): Unemployment dynamics during recessions and recoveries: Okun's law and beyond, in: World Economic Outlook, ch. 3.

IPCC (International Panel on Climate Change) (2014): Fifth Assessment Report (AR5) Working Group III: Summary for Policymakers.

Jackson, T. (2009): Prosperity without Growth - Economics for a Finite Planet, London: Earthscan. 
Jevons, W.S. (1865): The Coal Question: An Inquiry Concerning the Progress of the Nation, and the Probable Exhaustion of Our Coal-Mines, London: Macmillan.

Kallis, G. (2011): In defence of degrowth, in: Ecological Economics, 70(5), 873-880.

Kellie-Smith, O., Cox, P.M. (2011): Emergent dynamics of the climate-economy system in the Anthropocene, in: Philosophical Transactions of the Royal Society A: Mathematical, Physical and Engineering Sciences, 369(1938), 868-886.

Keynes, J.M. (1930 [1963]): Economic possibilities for our grandchildren, in: Essays in Persuasion, New York: W.W. Norton, 358-373.

Meadows, D.H., Meadows, D.L., Randers, J., Behrens, W.W. (1972): The Limits to Growth: A Report for the Club of Rome's Project on the Predicament of Mankind, New York: Universe Books.

Meadows, D.H., Randers, J., Meadows, D.L. (2004): Limits to Growth: The 30-Year Update, White River Junction, VT: Chelsea Green.

Nelson, J.A. (2008): Economists, value judgments, and climate change: a view from feminist economics, in: Ecological Economics, 65(3), 441-447.

Netzwerk Vorsorgendes Wirtschaften (2012): Wege Vorsorgenden Wirtschaftens, Marburg: Metropolis.

OECD (2011): The OECD Green Growth Strategy, Paris: OECD.

O'Neill, D.W. (2012): Measuring progress in the degrowth transition to a steady state economy, in: Ecological Economics, 84, 221-231.

Ponting, C. (1991): A Green History of the World, London: Sinclair-Stevenson.

Porritt, J. (2007): Capitalism as if the World Matters, London: Earthscan.

Rockström, J., Steffen, W., Noone, K., Persson, A., Stuart Chapin III, F., Lambin, E.F., Lenton, T.M., Scheffer, M., Folke, C., Schellnhuber, H.J., Nykvist, B., de Wit, C.A., Hughes, T., van der Leeuw, S., Rodhe, H., Sörlin, S., Snyder, P.K., Costanza, R., Svedin, U., Falkenmark, M., Karlberg, L., Corell, R.W., Fabry, V.J., Hansen, J., Walker, B., Liverman, D., Richardson, K., Crutzen, P., Foley, J.A. (2009): A safe operating space for humanity, in: Nature, 461(24 September), 472-475.

Schneider, F., Kallis, G., Martinez-Alier, J. (2010): Crisis or opportunity? Economic degrowth for social equity and ecological sustainability. Introduction to this special issue, in: Journal of Cleaner Production, 18(6), 511-518.

Schor, J. (1991): The Overworked American: The Unexpected Decline of Leisure, New York: Basic Books.

Sekulova, F., Kallis, G., Rodríguez-Labajos, B., Schneider, F. (2013): Degrowth: from theory to practice, in: Journal of Cleaner Production, 38, 1-6.

Sorman, A.H., Giampietro, M. (2013): The energetic metabolism of societies and the degrowth paradigm: analyzing biophysical constraints and realities, in: Journal of Cleaner Production, 38, 80-93.

Sorrell, S., Dimitropoulos, J. (2008): The rebound effect: microeconomic definitions, limitations and extensions, in: Ecological Economics, 65(3), 636-649.

Sorrell, S., Dimitropoulos, J., Sommerville, M. (2009): Empirical estimates of the direct rebound effect: a review, in: Energy Policy, 37(4), 1356-1371.

Stagl, S. (1999): Delinking economic growth from environmental degradation? A literature survey on the Environmental Kuznets Curve Hypothesis, Wirtschaftsuniversität Wien: 24.

Steffen, W., Grinevald, J., Crutzen, P., McNeill, J. (2011): The Anthropocene: conceptual and historical perspectives, in: Philosophical Transactions of the Royal Society A: Mathematical, Physical and Engineering Sciences, 369(1938), 842-867.

Stern, D. (2004): The rise and fall of the Environmental Kuznets Curve, in: World Development, 32(8), 1419-1439.

Stern, D.I., Common M.S., Barbier, E.B. (1996): Economic growth and environmental degradation: the environmental Kuznets curve and sustainable development, in: World Development, 24(7), 1151-1160.

Stockhammer, E. (2004): Financialisation and the slowdown of accumulation, in: Cambridge Journal of Economics, 28, 719-741.

Stockhammer, E., Hochreiter, H., Obermayr, B., Steiner, K. (1997): The index of sustainable economic welfare (ISEW) as an alternative to GDP in measuring economic welfare: the results of the Austrian (revised) ISEW calculation 1955-1992, in: Ecological Economics, 21(1), 19-34.

Tickell, C. (2011): Societal responses to the Anthropocene, in: Philosophical Transactions of the Royal Society A: Mathematical, Physical and Engineering Sciences, 369(1938), 926-932. 
Turner, G.M. (2008): A comparison of The Limits to Growth with 30 years of reality, in: Global Environmental Change, 18, 397-411.

UNDP (2013): Human Development Report 2013: The Rise of the South: Human Progress in a Diverse World.

van den Bergh, J.C.J.M. (2011): Environment versus growth - a criticism of 'degrowth' and a plea for 'a-growth', in: Ecological Economics, 70(5), 881-890.

van den Bergh, J.C.J.M., Grazi, F. (2014): Ecological footprint policy? Land use as an environmental indicator, in: Journal of Industrial Ecology, 18(1), 10-19.

van den Bergh, J.C.J.M., Kallis, G. (2012): Growth, A-growth or degrowth to stay within planetary boundaries? in: Journal of Economic Issues, 46(4), 909-919.

Victor, P.A. (2008): Managing Without Growth: Slower by Design, Not Disaster, Cheltenham, UK and Northampton, MA: Edward Elgar.

Victor, P.A. (2012): Growth, degrowth and climate change: a scenario analysis, in: Ecological Economics, 84, 206-212.

Vidas, D. (2011): The Anthropocene and the international law of the sea, in: Philosophical Transactions of the Royal Society A: Mathematical, Physical and Engineering Sciences, 369(1938), 909-925.

Videira, N., Schneider, F., Sekulova, F., Kallis, G. (2014): Improving understanding on degrowth pathways: an exploratory study using collaborative causal models, in: Futures, 55, 58-77.

Wackernagel, M. (2014): Comment on 'Ecological footprint policy? Land use as an environmental indicator', in: Journal of Industrial Ecology, 18(1), 20-23.

Wackernagel, M., Rees, W. (1996): Our Ecological Footprint: Reducing Human Impact on the Earth, Gabriola Island, British Columbia: New Society Publishers.

Weisz, H., Fischer-Kowalski, M., Grünbühel, C.M., Haberl, H., Krausmann, F., Winiwarter, V. (2001): Global environmental change and historical transitions, in: Innovation: The European Journal of Social Science Research, 14(2), 117-142.

Witt, U. (2001): Learning to consume - a theory of wants and the growth of demand, in: Journal of Evolutionary Economics, 11, 23-36.

Zalasiewicz, J., Williams, M., Haywood, A., Ellis, M. (2011): The Anthropocene: a new epoch of geological time? in: Philosophical Transactions of the Royal Society A: Mathematical, Physical and Engineering Sciences, 369(1938), 835-841. 